zeszyt $150,2017,95-117$

doi: 10.4467/20833113PG.17.019.7323

Instytut Geografii i Gospodarki Przestrzennej UJ

Wydawnictwo Uniwersytetu Jagiellońskiego

\title{
UCIĄŻLIWOŚĆ WARUNKÓW ODCZUWALNYCH PODCZAS DNI UPALNYCH PRZY RÓŻNEJ INTENSYWNOŚCI AKTYWNOŚCI FIZYCZNEJ (NA PRZYKŁADZIE PÓŁNOCNO-ZACHODNIEJ POLSKI)
}

\author{
Monika Okoniewska
}

\section{Uncomfortability of bio-thermal conditions during sweltering days at different intensity of physical activity (based on the area of north-western Poland)}

\begin{abstract}
The work is a description of onerousness of bio-thermal conditions occurring at midday during days of $\mathrm{t}_{\max } \geq 30^{\circ} \mathrm{C}$ in three towns located in north-western Poland: Kolobrzeg, Chojnice and Poznan, for people undertaking physical activity of varying intensity. Based on the meteorological data for 12 a.m. UTC from the period 1981-2016 average values of biometeorological (HIS, STI) and thermophysiologial (HR, Oh_H, SW, DhRna) indices, as well as their extreme values and amplitudes were calculated. The frequency of conditions burdening human body, when undertaking exercise outdoors, was also determined. The analyses showed that in the midday hours an increased physical activity leads to an increase in intense thermal sensations and a significant burdening of the human body with heat stress. A potential risk of overheating, that could occur within an hour of intense effort, was noted. A serious risk of dehydration of the body, even at moderate activity, was also indicated. Particularly burdening conditions, with high sultriness and a possibility of hyperthermia were observed in Kolobrzeg.
\end{abstract}

Keywords: sweltering days, sultriness, heart rate, dehydration, hyperthermia, physical activity 
Zarys treści: Praca zawiera charakterystykę uciążliwości warunków odczuwalnych występujących w południe w czasie dni $\mathrm{z}_{\max } \geq 30^{\circ} \mathrm{C} \mathrm{w}$ trzech miastach położonych w północno-zachodniej Polsce, tj. w Kołobrzegu, Chojnicach i Poznaniu, dla osób podejmujących aktywność fizyczną o różnej intensywności. Na podstawie danych meteorologicznych z godziny 12 UTC z lat 1981-2016 obliczono średnie wartości wskaźników biometeorologicznych (HSI, STI) i termofizjologicznych (HR, Oh_H, SW, DhRna), ich wartości ekstremalne oraz amplitudy, a także określono częstość stanów obciążających organizm człowieka, podejmującego wysiłek fizyczny w terenie otwartym. Analizy wykazały, że w godzinach okołopołudniowych zwiększenie aktywności fizycznej prowadzi do nasilenia intensywnych odczuć cieplnych oraz znacznego obciążenia organizmu stresem ciepła. Odnotowano możliwość wystąpienia ryzyka przegrzania, które przy intensywnym wysiłku mogło wystąpić już przed upływem godziny. Ponadto wykazano poważne niebezpieczeństwo odwodnienia już przy aktywności umiarkowanej. Szczególnie obciążające warunki pogodowe, cechujące się dużą parnością i możliwością wystąpienia hipertermii, stwierdzono w Kołobrzegu.

Stowa kluczowe: dni upalne, parność, częstotliwość tętna, odwodnienie, hipertermia, aktywność fizyczna

\section{Wstęp}

W ostatnich latach częstym przedmiotem zainteresowania klimatologów są groźne zjawiska pogodowe, zwłaszcza fale upałów. Wysoka temperatura powietrza powoduje bowiem poważne zagrożenie dla zdrowia i życia ludzi, czego przykładem może być ogromna liczba zgonów, jaka wystąpiła w czasie wyjątkowo upalnego lata roku 2003, kiedy zmarło, przeważnie z przyczyn niewydolności układu krążenia i oddechowego, ponad 35000 mieszkańców Europy Zachodniej i Południowej (Kozłowska-Szczęsna i in. 2004; Twardosz 2009). Wzrost częstości dni upalnych, jaki nastąpił w ostatnich dziesięcioleciach również na obszarze Polski, jest potwierdzony w licznych publikacjach (np. Cebulak, Limanówka 2007; Kossowska-Cezak, Skrzypczuk 2011; Koźmiński, Michalska 2011; Tomczyk 2012), a prognozowany przez niektórych naukowców dalszy ich przyrost (np. Kuchcik 2006), może stanowić istotne zagrożenie dla zdrowia i życia zwłaszcza osób starszych, dzieci i chorych, a dla służb ratowniczych może być dużym wyzwaniem organizacyjnym.

Nagromadzenie zbyt dużej ilości ciepła we wnętrzu ciała człowieka, spowodowane wysoką temperaturą otoczenia, może skutkować trwałym uszkodzeniem struktur białkowych komórek. Mechanizmy termoregulacyjne, zapewniające zrównoważenie ilości energii cieplnej docierającej do ustroju i od niego odprowadzanej, a tym samym chroniące przed przegrzaniem, mogą znacznie obciążać pracę narządów wewnętrznych, w szczególności serca. Wzrost temperatury powietrza powoduje bowiem rozszerzenie peryferycznych naczyń krwionośnych oraz zwiększenie skórnego przepływu krwi. Efektem ubocznym jest obniżenie ciśnienia tętniczego i wzrost tętna. Wysoka temperatura otoczenia powoduje także podwyższenie temperatury skóry, co 
z kolei przyczynia się do uaktywnienia gruczołów potowych (Kozłowska-Szczęsna i in. 2004; Błażejczyk, Kunert 2011). Odparowanie potu prowadzi do utraty wraz z wodą cennych składników mineralnych w tym sodu, chloru, potasu i magnezu, co może nieść z sobą poważne konsekwencje zdrowotne, takie jak problemy z zachowaniem właściwej równowagi elektrolitowej. Skutkiem odwodnienia jest zaburzenie szeregu funkcji fizjologicznych organizmu człowieka, które przyczyniać się mogą do znacznego osłabienia zdolności wysiłkowych, a w dalszej konsekwencji nawet stanowić zagrożenie dla zdrowia i życia (Mizera, Pilis 2008).

Odprowadzanie nadmiaru energii cieplnej drogą odparowania potu możliwe jest tylko wówczas, jeśli wysokiej temperaturze nie towarzyszy zbyt wysoka wilgotność powietrza (Kozłowska-Szczęsna i in. 2004). W przeciwnym razie parowanie jest znacznie utrudnione, a nawet może całkowicie ustać, co się może przyczynić do wystąpienia obciążającego układ krążenia stanu parności, a w skrajnych przypadkach nawet do śmierci z przegrzania.

Biorąc pod uwagę fakt, że godziny okołopołudniowe są okresem szczególnie często wykorzystywanym do różnego rodzaju zajęć rekreacyjnych czy sportowych, a także to, że wiele osób jest zmuszonych w tym czasie pracować fizycznie na powietrzu niezależnie od pogody, istotne jest, aby przyjrzeć się warunkom biotermicznym, występującym podczas dni upalnych, w szczególności specyfice zagrożeń, jakie mogą wynikać dla człowieka podejmującego aktywność w tak wysokiej temperaturze otoczenia.

\section{Cel pracy}

Celem opracowania była charakterystyka warunków odczuwalnych, występujących w godzinach okołopołudniowych w czasie dni upalnych, oraz ich oddziaływanie na człowieka podejmującego aktywność fizyczną o różnym stopniu intensywności. W szczególności ocenie poddano pojawiające się wówczas subiektywne odczucia cieplne, możliwość wystąpienia parności czy też wysokiego poziomu tętna mogącego stanowić zagrożenie dla zdrowia. Ponadto określono czas, po którym może dojść do niebezpiecznego stanu hipertermii, oraz oszacowano wielkości strat wody z organizmu człowieka i występującego ryzyka odwodnienia.

\section{Materiał i metody badań}

Materiał badawczy stanowiły pomiary meteorologiczne z dni upalnych, czyli dni, kiedy temperatura maksymalna w ciągu doby była wyższa lub równa od $30^{\circ} \mathrm{C}$ i w których nie odnotowano przejścia frontu atmosferycznego. 
W opracowaniu wykorzystano dane meteorologiczne z godziny 12 UTC, z trzech miast, położonych na obszarze północno-zachodniej Polski: Kołobrzegu, Chojnic i Poznania, pobrane z bazy danych Surface Data Hourly Global, zamieszczonej na serwerze NOAA (www7.ncdc.noaa.gov, 25.11.2016). Aby zweryfikować wiarygodność danych NOAA, wartości temperatury powietrza dla jednego miasta (Kołobrzegu) zostały porównane z wartościami pochodzącymi z IMGW. Otrzymane wielkości różnic nie przekraczały $0,4^{\circ} \mathrm{C}, \mathrm{z}$ czego można wywnioskować, iż dane pomiarowe pochodzące z bazy NOAA dobrze odzwierciedlają dane IMGW. Dane obejmowały następujące elementy meteorologiczne: temperaturę powietrza $\left(\mathrm{t},{ }^{\circ} \mathrm{C}\right)$, tempera-

Tab. 1. Położenie geograficzne stacji meteoroloturę punktu rosy $\left(\mathrm{td},{ }^{\circ} \mathrm{C}\right)$, prędkość gicznych

Table 1. Geographical location of meteorological stations

\begin{tabular}{|c|c|c|c|}
\hline $\begin{array}{c}\text { Stacja } \\
\text { Station }\end{array}$ & $\varphi$ & $\lambda$ & $\begin{array}{c}\text { hs } \\
\text { (m n.p.m.) }\end{array}$ \\
\hline Kołobrzeg & $54^{\circ} 11^{\prime} \mathrm{N}$ & $15^{\circ} 35^{\prime} \mathrm{E}$ & 5 \\
\hline Chojnice & $53^{\circ} 42^{\prime} \mathrm{N}$ & $17^{\circ} 33^{\prime} \mathrm{E}$ & 172 \\
\hline Poznań-Ławica & $5^{\circ} 25^{\prime} \mathrm{N}$ & $1^{\circ} 50^{\prime} \mathrm{E}$ & 86 \\
\hline
\end{tabular}

Źródto: http://www.weatheronline.pl/weather/maps/. Source: http://www.weatheronline.pl/weather/maps/.

Tab. 2. Liczba dni upalnych $\left(\mathrm{t}_{\max } \geq 30^{\circ} \mathrm{C}\right)$ na obszarze północno-zachodniej Polski (1981-2016)

Table 2. Number of sweltering days in the area of north-western Poland (1981-2016)

\begin{tabular}{|c|c|c|c|}
\hline & Kołobrzeg & Chojnice & Poznań \\
\hline Kwiecień / April & 0 & 0 & 2 \\
\hline Maj / May & 4 & 1 & 12 \\
\hline Czerwiec / June & 10 & 21 & 52 \\
\hline Lipiec /July & 35 & 77 & 155 \\
\hline Sierpień / August & 29 & 48 & 109 \\
\hline Wrzesień / September & 2 & 1 & 9 \\
\hline Razem / Total & 80 & 148 & 339 \\
\hline
\end{tabular}
wiatru $\left(\mathrm{v}, \mathrm{m} \cdot \mathrm{s}^{-1}\right)$ oraz zachmurzenie (N, oktanty), z dni upalnych lat 1981-2016. Położenie geograficzne stacji meteorologicznych wykorzystanych w opracowaniu zobrazowano w tab. 1.

Kołobrzeg położony jest w pasie Pobrzeży Południowobałtyckich, na Wybrzeżu Słowińskim, w regionie bioklimatycznym o silnej bodźcowości, mocno podlegającym wpływom Bałtyku (Kozłowska-Szczęsna $i$ in. 2002). Stacja meteorologiczna znajduje się między miastem a uzdrowiskiem, w obrębie niskiej, lecz gęstej zabudowy jednorodzinnej. Ochładzające w okresie letnim oddziaływanie Morza Bałtyckiego powoduje, że średnia temperatura powietrza $\mathrm{w}$ tym czasie jest niższa niż w głębi lądu, co wpływa na mniejszą liczbę dni upalnych. W badanych latach 1981-2016 wystąpiło ich 80 (tab. 2), najczęściej w miesiącach letnich - w lipcu i sierpniu - średnio 2,2 dnia w roku.

Chojnice leżą w obrębie wzniesień morenowych Pojezierza Południowobałtyckiego, na Pojezierzu Krajeńskim (Kondracki 2002). 
Stacja meteorologiczna jest położona w strefie podmiejskiej, w terenie otwartym, w obrębie terenów leśnych. Urozmaicona rzeźba terenu oraz liczne jeziora sprawiają, że lata są tu raczej chłodne i krótkie. W związku z tym nie występuje tu zbyt duża liczba dni upalnych. Jest ich zdecydowanie mniej niż w Poznaniu, choć blisko dwukrotnie więcej niż w pasie pobrzeża. W rozpatrywanych okresie zaobserwowano 148 takich dni (tab. 2), co daje średnio 4,1 dni upalnych w roku, przy czym w większości występowały one w lipcu.

Poznań znajduje się na obszarze Pojezierza Wielkopolskiego, o znacznie mniej urozmaiconej rzeźbie terenu (Kondracki 2002). Stacja meteorologiczna jest zlokalizowana na płycie lotniska Poznań-Ławica, na obszarze pozbawionym wszelkich naturalnych i sztucznych przeszkód. W latach 1981-2016 wystąpiło tu 339 dni upalnych, co odpowiada 9,4 takich dni rocznie. Maksimum ich występowania było w lipcu - 155 dni upalnych (średnio 4,3), choć i w sierpniu ich liczba była stosunkowo duża w porównaniu z Kołobrzegiem i Chojnicami, przekraczała bowiem $100 \mathrm{dni}(3,0)$. Ponadto w Poznaniu, jako jedynej stacji dni $\mathrm{z} \mathrm{t}{ }_{\max } \geq 30^{\circ} \mathrm{C}$ pojawiły się już w kwietniu (tab. 2).

Przeprowadzone obliczenia wskazują, że uśrednione z lat 1981-2016 wartości temperatury powietrza we wszystkich trzech stacjach w dniach upalnych o godzinie 12 UTC, były do siebie zbliżone i wynosiły około $30^{\circ} \mathrm{C}$. Różnice między stacjami zaznaczyły się natomiast w przypadku wilgotności powietrza. Największą średnią wilgotnością względną (43,3\%) cechował się Kołobrzeg, co wynika z jego położenia w strefie wybrzeża. W pozostałych miejscowościach wilgotność względna powietrza była nieco niższa. Ponadto dni upalne odznaczały się umiarkowanymi prędkościami wiatru, nieprzekraczającymi nad morzem $3 \mathrm{~m} \cdot \mathrm{s}^{-1}$, a w Chojnicach dochodzących do nieco ponad $4 \mathrm{~m} \cdot \mathrm{s}^{-1}$. Średnie wartości zachmurzenia wyniosły 3-4 oktantów, czyli ok. 40-50\% pokrycia nieba (tab. 3).

Podstawą pracy była analiza średnich wartości wybranych wskaźników biometeorologicznych oraz termofizjologicznych z godziny 12 UTC, ich średnich wartości ekstremalnych oraz amplitud, obliczonych jako różnice między oszacowanymi wcześniej uśrednionymi wartościami maksymalnymi i minimalnymi. Pozwoliło to na zbadanie wielkości zróżnicowania występujących charakterystyk. Ponadto okre-

Tab. 3. Charakterystyka warunków meteorologicznych o godz. 12 UTC w dniach upalnych na obszarze północno-zachodniej Polski (1981-2016) Table 3. Characteristics of meteorological conditions at 12 a.m. UTC during sweltering days in the area of north-western Poland (1981-2016)

\begin{tabular}{|c|c|c|c|}
\hline & Kołobrzeg & Chojnice & Poznań \\
\hline $\mathrm{t}\left({ }^{\circ} \mathrm{C}\right)$ & 29,8 & 30,2 & 30,2 \\
\hline $\mathrm{f}(\%)$ & 43,3 & 39,3 & 36,7 \\
\hline $\mathrm{v}\left(\mathrm{m} \cdot \mathrm{s}^{-1}\right)$ & 2,8 & 4,1 & 3,7 \\
\hline $\begin{array}{c}\mathrm{N} \\
\text { (oktanty / octants) }\end{array}$ & 3,5 & 4,3 & 2,9 \\
\hline
\end{tabular}


ślono częstość stresu cieplnego oraz rodzajów subiektywnego odczucia cieplnego, a także stanów termofizjologicznych, zagrażających zdrowiu i życiu człowieka, w szczególności: intensywności parności, niebezpiecznego poziomu częstotliwości tętna, czasu, po którym może dojść do hipertermii, czy ryzyka odwodnienia.

Przeprowadzone analizy dotyczyły osób podejmujących aktywność fizyczną o różnej intensywności. Określenia aktywności fizycznej dokonano na podstawie wartości metabolicznej produkcji ciepła, wytwarzanej pod wpływem wysiłku fizycznego, przy czym prezentowane wartości metabolizmu odnosiły się do tzw. średniego człowieka (wiek 30 lat, wzrost $175 \mathrm{~cm}$, ciężar $75 \mathrm{~kg}$ ), o metabolizmie podstawowym równym $45 \mathrm{~W} \cdot \mathrm{m}^{-2}$ (Błażejczyk 2004). Wyznaczono trzy poziomy aktywności:

1. Aktywność fizyczna niewielka - odpoczynek w pozycji siedzącej, odpowiadający metabolicznej produkcji ciepła w wysokości $60 \mathrm{~W} \cdot \mathrm{m}^{-2}$;

2. Aktywność fizyczna umiarkowana - spacer z prędkością $4 \mathrm{~km} \cdot \mathrm{h}^{-1}$, odpowiadający metabolicznej produkcji ciepła w wysokości $135 \mathrm{~W} \cdot \mathrm{m}^{-2}$;

3. Aktywność fizyczna intensywna - szybki marsz z prędkością $8 \mathrm{~km} \cdot \mathrm{h}^{-1}$, odpowiadający metabolicznej produkcji ciepła w wysokości $290 \mathrm{~W} \cdot \mathrm{m}^{-2}{ }^{2}$

W pracy zastosowano następujące wskaźniki biometeorologiczne i termofizjologiczne, obliczone za pomocą programu BioKlima ver. 2.6 (https://www.igipz.pan.pl/ Bioklima-zgik.html, 5.01.2017):

Wskaźnik stresu cieplnego (HSI - Heat Stress Index, w \%) -ilustruje natężenie uciążliwości warunków termiczno-wilgotnościowych oraz odczucia parności. Jest on stosunkiem ewaporacyjnych strat ciepła niezbędnych do zachowania równowagi cieplnej organizmu do ewaporacyjnych strat ciepła, maksymalnych w danych warunkach meteorologicznych. Poszczególnym wartościom HSI są przypisane następujące rodzaje efektów fizjologicznych (Błażejczyk, Kunert 2011):

\footnotetext{
HSI (\%) efekt fizjologiczny;

$\leq 0,0 \quad$ lagodny stres chłodu;

0,1-10,0 brak obciążenia termiczno-wilgotnościowego;

10,1-30, łagodny lub umiarkowany stres termiczno-wilgotnościowy;

30,1-70,0 silny stres termiczno-wilgotnościowy; uciążliwy w przypadku braku aklimatyzacji oraz dla osób starszych, osób chorych na astmę lub nadciśnienie tętnicze;

70,1-90,0 bardzo silny stres termiczno-wilgotnościowy; uciążliwy dla wszystkich grup osób;

90,1-100,0 maksymalny stres termiczno-wilgotnościowy, niebezpieczny dla zdrowia osób z grup ryzyka, tolerowany, ale bardzo uciążliwy, w przypadku osób młodych i zaaklimatyzowanych;
} 
$>100,0$ niebezpieczeństwo podwyższenia temperatury wewnętrznej u wszystkich osób;

czas przebywania w takich warunkach musi być nadzorowany.

Na podstawie wskaźnika HSI określono występowanie odczucia parności według następujących kryteriów (Błażejczyk 2004):

HSI (\%) intensywność parności;

$<30 \quad$ brak parności;

30-70 parność umiarkowana, dokuczliwa dla osób starszych i dzieci oraz osób niezaaklimatyzowanych;

>70 parność uciążliwa dla wszystkich osób, w przypadku osób starszych i dzieci może powodować przegrzanie organizmu.

Wskaźnik temperatury odczuwalnej (STI - Subjective Temperature Index, $\mathbf{w}^{\circ} \mathbf{C}$ ) - jego podstawą jest średnia temperatura promieniowania, która odzwierciedla natężenie bodźców termicznych otoczenia docierających do zewnętrznych warstw odzieży noszonej przez człowieka w danych warunkach pogodowych, kształtująca się pod wpływem temperatury otoczenia i ilości pochłoniętego promieniowania słonecznego. STI uwzględnia także saldo wymiany ciepła pomiędzy człowiekiem a otoczeniem (Błażejczyk 2004).

Rodzaje subiektywnych odczuć cieplnych są określane według skali:

STI $\left({ }^{\circ} \mathrm{C}\right) \quad$ rodzaj subiektywnego odczucia cieplnego;

$<-38,0^{\circ} \mathrm{C} \quad-$ mroźnie;

$-38,0$ do -20,1- bardzo zimno;

-20,0 do -0,5-zimno;

$-0,4$ do 22,5 - chłodno;

22,6 do 32,0 - komfortowo;

32,1 do 46,0 - ciepło;

46,1 do 55,0 - gorąco;

55,1 do 70,0 - bardzo gorąco;

$>70,0 \quad-$ upalnie.

Wskaźnik częstotliwości tętna (HR - Heart Rate, liczba uderzeń.min. $\left.{ }^{-1}\right)$ określa liczbę uderzeń serca w ciągu minuty. Na wartość HR mają wpływ zarówno aktywność fizyczna człowieka, jak i niektóre parametry meteorologiczne. Wartość wskaźnika HR wzrasta wraz ze wzrostem temperatury powietrza i ciśnienia pary wodnej oraz ze zwiększeniem wysiłku fizycznego (Błażejczyk, Kunert 2011). 
Wskaźnik ryzyka przegrzania (Oh_H - Hyperthermia Risk, w min.) określa czas, po którym następuje zbyt duże nagromadzenie ciepła w organizmie i może dojść do stanu hipertermii. Czas ten można obliczyć na podstawie podstawowej i wynikowej wartości salda wymiany ciepła (Błażejczyk, Kunert 2011).

Wskaźnik strat wody (SW - Water loss, w g.godz. ${ }^{-1}$ ) - wskazuje, ile wody należy dostarczyć do organizmu, aby uchronić go przed odwodnieniem. Wskaźnik jest szczególnie przydatny w przypadku aktywnej rekreacji i turystyki pieszej uprawianej w wysokiej temperaturze otoczenia (Błażejczyk, Kunert 2011).

Wskaźnik ryzyka odwodnienia (DhRna - Dehydration Risk) - wskaźnik ilustrujący stopień narażenia organizmu na odwodnienie osób niezaaklimatyzowanych. Ryzyko odwodnienia jest zależne od stopnia zaaklimatyzowania i stanu aktywności fizycznej człowieka.

Zgodnie z normą ISO/DIS 7933 u niezaaklimatyzowanych osób odwodnienie prawdopodobne występuje, gdy $520<\mathrm{SW}<650$ g.godz. $^{-1}$, odwodnienie pewne przy wartościach przekraczających 650 g.godz. ${ }^{-1}$ (Błażejczyk, Kunert 2011).

Wybrane wskaźniki odnoszą się do różnych reakcji fizjologicznych organizmu człowieka, zachodzących pod wpływem wysokiej temperatury otoczenia. Pozwoliły więc na ukazanie wieloaspektowego charakteru uciążliwości warunków pogodowych, w tym stanów zagrażających zdrowiu i życiu człowieka.

\section{Temperatura odczuwalna (Subjective Temperature Index)}

Wraz ze wzrostem intensywności aktywności fizycznej wzrasta subiektywna temperatura odczuwalna. Otrzymane średnie wartości wskaźnika STI oznaczają, że w upalne godziny okołopołudniowe przy niskim i umiarkowanym poziomie aktywności fizycznej we wszystkich miastach spodziewać się należało klasy odczucia „gorąco”, a przy bardziej intensywnej aktywności, odpowiadającej np. szybkiemu marszowi, nad morzem i w Poznaniu byłaby to już klasa odczucia określana jako „bardzo gorąco". Zakres występowania wartości maksymalnych wskaźnika świadczy o tym, że w rozpatrywanych latach zdarzały się takie dni, w których już samo przebywanie w tak ekstremalnych warunkach wiązało się z możliwością wystąpienia klasy odczucia cieplnego „bardzo gorąco”. Wzrost aktywności fizycznej do bardziej intensywnego poziomu powodował natomiast możliwość wystąpienia rodzaju odczucia cieplnego, określanego jako , upalne” nad morzem, oraz występowanie warunków zbliżonych do tej kategorii w Chojnicach i Poznaniu. Minimalne wartości wskaźnika w przypadku niewielkiej aktywności fizycznej kształtowały się w przedziale wartości świadczących o możliwości odczuwania „chłodu”, a przy aktywności fizycznej odpowiadającej metabolicznej produkcji ciepła $290 \mathrm{~W} \cdot \mathrm{m}^{-2}$ wskazywały na występowanie warunków „komfortowych”. Oznacza to, że dni upalne mogą się cechować różnorodnością poja- 
wiających się odczuć cieplnych. Potwierdza to także wysoka amplituda wskaźnika STI, przekraczająca przy każdym rodzaju aktywności $40^{\circ} \mathrm{C}$ i świadcząca o tym, iż niezależnie od intensywności wysiłku fizycznego w godzinach okołopołudniowych dni upalnych subiektywne odczucia cieplne mogą zmieniać się od klasy „chłodno”, aż do klasy „upalnie” (tab. 4).

Rozpatrując częstość różnych rodzajów odczuć cieplnych, trzeba zauważyć, że osoby odpoczywające w pozycji siedzącej w dniach upalnych w południe najczęściej odczuwały „gorąco”, w dalszej kolejności „bardzo gorąco” nad morzem, „komfortowo” w Chojnicach i „ciepło” w Poznaniu. Chojnice odznaczały się największym zróżnicowaniem klas odczucia cieplnego, które tam także były najmniej obciążające, bez względu na intensywność wysiłku fizycznego. W czasie odpoczynku i umiarkowanej aktywności najrzadziej obserwowano tam odczucia „bardzo gorąco” na rzecz „komfortu termicznego”, a sporadycznie mogły pojawić się wrażenia „chłodu”. Warunki komfortowe, panujące w czasie odpoczynku lub przy umiarkowanej aktywności, zaznaczały się spośród badanych miast, najrzadziej w Poznaniu - jedynie w 3-4\% dni upalnych. Podejmowanie intensywnej aktywności fizycznej, wiążącej się z metaboliczną produkcją ciepła $290 \mathrm{~W} \cdot \mathrm{m}^{-2}$, sprawiało, że w upalne południa z przeważającą częstością należało liczyć się z odczuciami „bardzo gorąco”. „Komfort termiczny" odnotowano w tym przypadku w około 5,5\% sytuacji w Chojnicach i sporadycznie w Kołobrzegu. Nad morzem zwiększenie wysiłku fizycznego mogło także spowodować chwilowe zintensyfikowanie odczuć cieplnych do poziomu „upalnie” (ryc. 1).

Tab. 4. Średnie, maksymalne i minimalne oraz amplitudy wskaźnika STI $\left({ }^{\circ} \mathrm{C}\right) \mathrm{w}$ dniach upalnych o godzinie 12 UTC przy różnej aktywności fizycznej na obszarze północnozachodniej Polski (1981-2016)

Table 4. Average, maximum and minimum values as well as amplitudes of the STI $\left({ }^{\circ} \mathrm{C}\right)$ during sweltering days at 12 a.m. UTC at different physical activity in the area of north-western Polish (1981-2016)

\begin{tabular}{|c|c|c|c|c|c|c|c|c|c|}
\hline \multirow{2}{*}{\begin{tabular}{c} 
Stacja / Station \\
\cline { 2 - 10 } M (W.m- $\left.{ }^{-2}\right)$
\end{tabular}} & 60 & 135 & 290 & 60 & 135 & 290 & 60 & 135 & 290 \\
\hline śr. STI $\left({ }^{\circ} \mathrm{C}\right)$ & 48,9 & 51,7 & 56,0 & 44,8 & 47,5 & 52,3 & 49,3 & 52,1 & 56,8 \\
\hline $\operatorname{maxSTI}\left({ }^{\circ} \mathrm{C}\right)$ & 65,9 & 67,7 & 71,0 & 62,1 & 64,1 & 67,5 & 61,9 & 64,0 & 67,6 \\
\hline $\operatorname{minSTI}\left({ }^{\circ} \mathrm{C}\right)$ & 22,9 & 24,4 & 28,0 & 19,6 & 21,1 & 24,5 & 19,7 & 21,1 & 24,5 \\
\hline$\Delta \mathrm{STI}\left({ }^{\circ} \mathrm{C}\right)$ & 43,0 & 43,3 & 43,0 & 42,5 & 43,0 & 43,0 & 42,2 & 42,9 & 43,0 \\
\hline
\end{tabular}




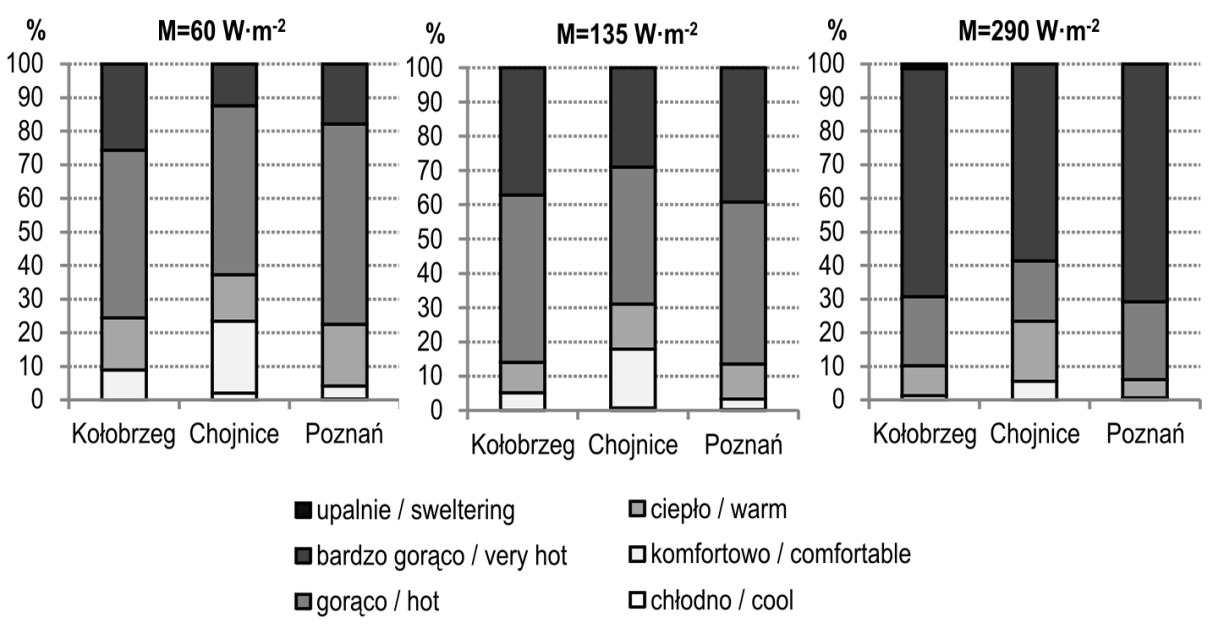

Ryc. 1. Częstość (\%) rodzajów subiektywnych odczuć cieplnych w dniach upalnych o godzinie 12 UTC przy różnej aktywności fizycznej na obszarze północno-zachodniej Polski (1981-2016) Fig. 1. Frequency (\%) of subjective thermal sensations during sweltering days at 12 a.m. UTC at different physical activity in the area of north-western Poland (1981-2016)

\section{Stres cieplny (Heat Stress Index)}

Średnie wartości wskaźnika stresu cieplnego w południe w dniach upalnych przy odpoczynku w pozycji siedzącej $\left(\mathrm{M}=60 \mathrm{~W} \cdot \mathrm{m}^{-2}\right)$, znajdowały się w przedziale oznaczającym „łagodny lub umiarkowany stres ciepła”. Zwiększenie aktywności fizycznej do poziomu odpowiadającego metabolicznej produkcji ciepła $135 \mathrm{~W} \cdot \mathrm{m}^{-2}$, czyli np. spaceru po równinie, spowodowałoby kilkunastoprocentowy wzrost średniej wartości HSI, lecz jedynie nad morzem oznaczałoby to możliwość wystąpienia „silnego stresu ciepła”, który mógł stanowić zagrożenie dla zdrowia ludzi chorych na astmę lub nadciśnienie tętnicze. Wzrost zaś metabolicznej produkcji ciepła do wartości $290 \mathrm{~W} \cdot \mathrm{m}^{-2}$ doprowadziłby do pojawienia się tego rodzaju obciążenia cieplnego we wszystkich miastach. W okresie 1981-2016 zdarzały się także dni, kiedy stopień zagrożenia stresem ciepła w południe był wyjątkowo duży już przy umiarkowanej aktywności fizycznej. Otrzymano bowiem maksymalne wartości wskaźnika, przekraczające $100 \%$ (w przypadku metabolicznej produkcji ciepła w wysokości $135 \mathrm{~W} \cdot \mathrm{m}^{-2}$ i większej), świadczące o istniejącym niebezpieczeństwie podwyższenia wewnętrznej temperatury ciała. Dane wskazują, że nawet bierny odpoczynek mógł wiązać się ze zbyt dużym prawdopodobieństwem przegrzania dla osób z grup 
ryzyka, a aktywność intensywna mogła być bardzo niebezpieczna dla wszystkich osób. Przeprowadzone analizy wykazały także, że w badanym okresie zdarzały się dni upalne, przy których aktywność fizyczna w godzinach okołopołudniowych nie stanowiła aż tak dużego zagrożenia dla zdrowia. Wartości minimalne HSI w Chojnicach i Poznaniu przy wysiłku odpowiadającym metabolizmowi $60 \mathrm{~W} \cdot \mathrm{m}^{-2}$ (odpoczynek w pozycji siedzącej) wskazywały na występowanie „łagodnego stresu chłodu”, podczas gdy w Kołobrzegu informowały o „braku obciążenia cieplnego”. W dniach takich także podjęcie umiarkowanej aktywności nie wiązało się z żadnym ryzykiem nasilenia stresu ciepła, natomiast zwiększenie aktywności fizycznej odpowiadającej metabolizmowi $290 \mathrm{~W} \cdot \mathrm{m}^{-2}$ wskazywało na pojawienie się jedynie „łagodnego” lub „umiarkowanego stresu ciepła” (tab. 5).

Obliczona amplituda wskaźnika stresu cieplnego wskazuje, że w dniach upalnych szczególnie duże zróżnicowanie warunków biotermicznych wystąpiło przy najbardziej intensywnej aktywności fizycznej (tab. 5).

Analiza częstości wartości HSI w przedziałach intensywności stresu cieplnego wykazała, że dla osób jedynie odpoczywających w godzinach okołopołudniowych w dniach upalnych, dominującym rodzajem stresu cieplnego był „łagodny lub umiarkowany stres ciepła” (ryc. 2). Z częstością od około $18 \%$ nad morzem do około 38\% w Chojnicach pojawiały się sytuacje nieobciążające organizmu człowieka jakimkolwiek stresem termicznym. Ponadto w Chojnicach wystąpiły pojedyncze dni, kiedy odpoczynek na powietrzu w południe wiązał się z pojawieniem „łagodnego stresu chłodu”. Przy zwiększeniu aktywności fizycznej do poziomu umiarkowanego wzrastała częstość „silnego stresu ciepła”, zdecydowanie zaś spadała częstość dni, w których nie było obciążenia termiczno-wilgotnościowego.

Tab. 5. Średnie, maksymalne i minimalne oraz amplitudy wskaźnika HSI (\%) w dniach upalnych o godzinie 12 UTC przy różnej aktywności fizycznej na obszarze północno-zachodniej Polski (1981-2016)

Table 5. Average, maximum and minimum values as well as amplitudes of the HSI (\%) during sweltering days at 12 a.m. UTC at different physical activity in the area of north-western Poland (1981-2016)

\begin{tabular}{|c|c|r|r|r|r|r|r|r|r|}
\hline Stacja / Station & \multicolumn{4}{|c|}{ Kołobrzeg } & \multicolumn{3}{c|}{ Chojnice } & \multicolumn{3}{c|}{ Poznań } \\
\cline { 2 - 11 } M (W.m $\left.{ }^{-2}\right)$ & 60 & 135 & 290 & 60 & 135 & 290 & 60 & 135 & 290 \\
\hline śr. HSI (\%) & 17,7 & 33,6 & 66,6 & 13,6 & 26,6 & 53,4 & 14,6 & 27,1 & 52,8 \\
\hline HSImax (\%) & 65,1 & 102,6 & 180,1 & 86,7 & 151,9 & 286,8 & 97,5 & 164,2 & 302,1 \\
\hline HSImin (\%) & 1,3 & 9,2 & 22,9 & $-1,0$ & 5,0 & 17,3 & $-2,0$ & 5,6 & 19,3 \\
\hline$\Delta$ HSI (\%) & 63,7 & 93,4 & 157,2 & 87,7 & 147,0 & 269,5 & 99,5 & 158,6 & 282,8 \\
\hline
\end{tabular}




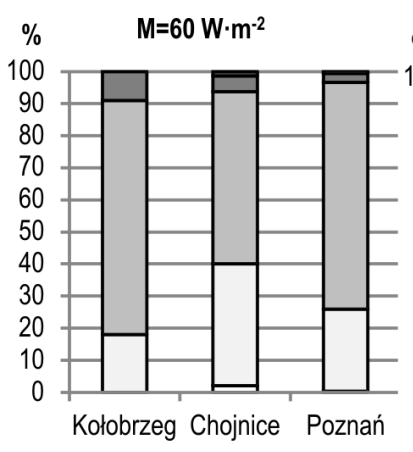

- niebezpieczeństwo przegrzania organizmu / hazard of overheating

口maksymalny tolerowany stres ciepła / maximum torelable heat stress

口bardzo silny stres ciepła / very intensive heat stress

$\square$ silny stres ciepla / intensive heat stress
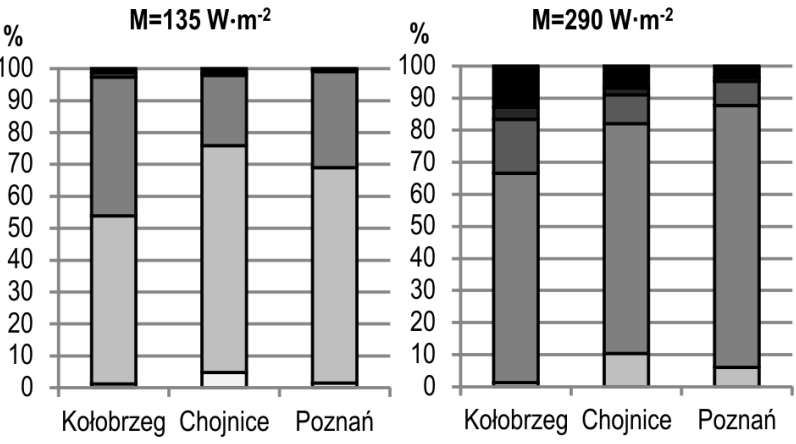

Ryc. 2. Częstość (\%) stresu cieplnego w dniach upalnych o godzinie 12UTC przy różnej aktywności fizycznej na obszarze północno-zachodniej Polski (1981-2016)

Fig. 2. Frequency (\%) of heat stress during sweltering days at 12 a.m. UTC at different physical activity in the area of north-western Poland (1981-2016)

Mimo to niezbyt intensywny wysiłek nie prowadził jeszcze do istotnego wzrostu częstości warunków silnie obciążających. Nasiliły się one dopiero w przypadku wykonywania bardziej intensywnych zajęć ruchowych, np. szybkiego marszu, truchtu, kiedy odnotowano sytuacje wystąpienia „bardzo silnego stresu ciepła”, „stresu ciepła tolerowanego jedynie przez osoby młode i zaaklimatyzowane, a także „niebezpieczeństwa przegrzania u wszystkich osób”. Większość analizowanych dni w warunkach podejmowania intensywnych ćwiczeń lub pracy w terenie otwartym wiązała się natomiast z występowaniem „silnego stresu ciepła”, uciążliwego dla osób niezaaklimatyzowanych, starszych lub chorych na choroby układu oddechowego czy krążenia. W nielicznych przypadkach odnotowano możliwość pojawiania się „łagodnego” lub „umiarkowanego stresu termiczno-wilgotnościowego" (ryc. 2). 


\section{Parność (Sultriness)}

Odczucie parności nasila się wraz z intensywnością aktywności fizycznej. U osób jedynie odpoczywających w południe w terenie otwartym częstość takich sytuacji była nieznaczna. Wzrost wysiłku fizycznego, odpowiadającego metabolicznej produkcji ciepła $135 \mathrm{~W} \cdot \mathrm{m}^{-2}$, wiązał się ze zwiększeniem częstości doświadczania dokuczliwych stanów parności w stopniu umiarkowanym, sporadycznie mogły pojawić się sytuacje określane, jako „bardzo parne”. Osoby, które podjęłyby natomiast bardziej intensywny wysiłek fizyczny, w zdecydowanej większości przypadków odczułyby parność, przynajmniej umiarkowaną. Nad morzem w około 33\% przypadków stwierdzono warunki charakteryzujące się bardzo dużą parnością. W Chojnicach i Poznaniu występowały one rzadziej, nieco częściej w sytuacjach zwiększonej aktywności zdarzały się przypadki braku odczuwania parności powietrza atmosferycznego (ryc. 3).

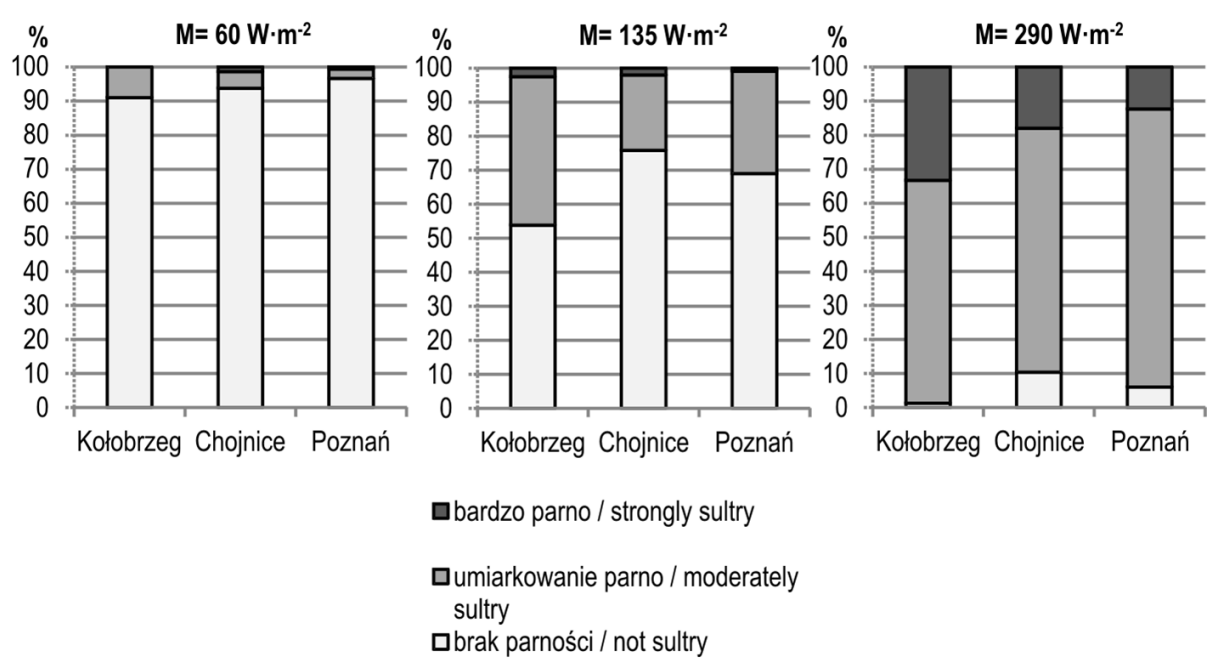

Ryc. 3. Częstość (\%) odczucia parności w dniach upalnych o godzinie 12 UTC przy różnej aktywności fizycznej na obszarze północno-zachodniej Polski (1981-2016)

Fig. 3. Frequency (\%) of sultriness during sweltering days at 12 a.m. UTC at different physical activity in the area of north-western Poland (1981-2016) 


\section{Częstotliwość tętna (Heart Rate)}

Średnia wartość tętna u osób odpoczywających na powietrzu w upalne godziny okołopołudniowe, we wszystkich miastach, kształtowała się na poziomie 81-82 uderzeń na minutę, co u kobiet jest wartością w normie, dla mężczyzn natomiast jest wielkością nieco podwyższoną. Zwiększenie wysiłku fizycznego już do poziomu umiarkowanego mogło jednak spowodować przekroczenie bezpiecznej wartości 90 uderzeń na minutę. W przypadku umiarkowanej aktywności fizycznej przekroczenie to jeszcze nie było duże. Dalsze zwiększanie aktywności mogło być niebezpieczne, gdyż metaboliczna produkcja ciepła związana np. z truchtem mogła spowodować wzrost tętna do 123-124 uderzeń na minutę. Analiza najwyższych wartości wskaźnika HR w dniach upalnych pokazuje, że w badanym okresie pojawiały się dni, kiedy także bierny odpoczynek mógł powodować pewne obciążenie układu krążenia. Przy intensywnej aktywności fizycznej w najbardziej uciążliwych warunkach biotermicznych tętno mogło wzrosnąć nawet do blisko 140 uderzeń na minutę (w Kołobrzegu). W dniach upalnych, w godzinach okołopołudniowych, zdarzały się również przypadki, kiedy tętno nawet przy umiarkowanej aktywności nie wzrastało do poziomu groźnego dla zdrowia. Nie było natomiast sytuacji, aby warunki takie umożliwiały bezpieczne podejmowanie intensywnego wysiłku fizycznego (tab. 6).

Analiza różnic między najwyższą a najniższą częstotliwością tętna wskazuje, że w dniach upalnych im większa była intensywność wysiłku fizycznego, tym mniejsze zróżnicowanie częstotliwości tętna (tab. 6).

Niezależnie od rodzaju podejmowanej aktywności fizycznej, w dniach upalnych, w godzinach okołopołudniowych, częstotliwość tętna u mężczyzn zawsze była zbyt

Tab. 6. Średnie, maksymalne, minimalne, oraz amplitudy częstotliwości tętna (uderz. $\cdot \min ^{-1}{ }^{-1}$ ) w dniach upalnych o godzinie 12 UTC przy różnej aktywności fizycznej na obszarze północno-zachodniej Polski (1981-2016)

Table 6. Average, maximum and minimum values as well as amplitudes of heart rate (beats per minute) during sweltering days at 12 a.m. UTC at different physical activity in the area of north-western Poland (1981-2016)

\begin{tabular}{|c|c|c|c|c|c|c|c|c|c|}
\hline Stacja / Station & \multicolumn{3}{|c|}{ Kołobrzeg } & \multicolumn{3}{c|}{ Chojnice } & \multicolumn{3}{c|}{ Poznań } \\
\hline M (W.m-2 $)$ & 60 & 135 & 290 & 60 & 135 & 290 & 60 & 135 & 290 \\
\hline śr. HR (uderz. min. $^{-1}$ ) & 82 & 96 & 124 & 82 & 96 & 123 & 81 & 95 & 123 \\
\hline maxHR (uderz. min. $^{-1}$ ) & 97 & 111 & 139 & 93 & 107 & 135 & 90 & 104 & 132 \\
\hline minHR (uderz. $\cdot$ min. $^{-1}$ ) & 74 & 88 & 116 & 75 & 88 & 116 & 73 & 86 & 114 \\
\hline$\Delta$ HRR (uderz. min. $^{-1}$ ) & 23 & 23 & 23 & 19 & 19 & 19 & 18 & 18 & 18 \\
\hline
\end{tabular}




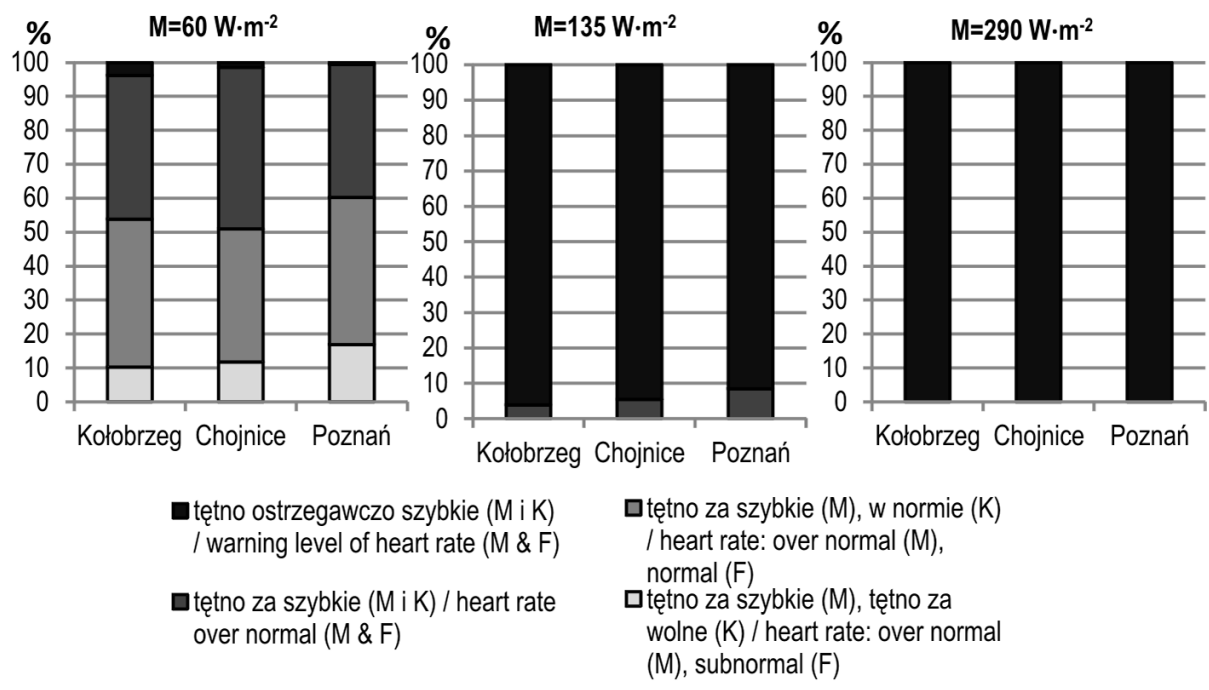

Ryc. 4. Częstość (\%) różnych zakresów częstotliwości tętna w dniach upalnych o godzinie 12 UTC przy różnej aktywności fizycznej na obszarze północno-zachodniej Polski (1981-2016) Fig. 4. Frequency (\%) of different ranges of heart rate during sweltering days at 12 a.m. UTC at different physical activity in the area of north-western Poland (1981-2016)

wysoka. Brak wysiłku fizycznego powodował, że z częstością blisko $40 \%$ zdarzały się sytuacje, kiedy u kobiet wystąpiła wartość tętna była w normie, czasami było ono nawet zbyt wolne. We wszystkich stacjach blisko połowa warunków pogodowych wiązała się jednak ze zbyt wysokim tętnem niezależnie od płci, a w sporadycznych przypadkach kształtowało się ono już na poziomie ostrzegawczym. Wzrost aktywności fizycznej do umiarkowanej wiązał się z tym, że częstotliwość tętna była zbyt szybka zarówno u mężczyzn, jak i u kobiet, przy czym w ponad $90 \%$ było to tętno ostrzegawczo szybkie. Natomiast podejmowanie intensywnej aktywności fizycznej we wszystkich dniach mogło bezwzględnie prowadzić do bardzo niebezpiecznej dla zdrowia sytuacji nadmiernego obciążenia serca (ryc. 4).

\section{Ryzyko wystąpienia hipertermii (Hypertermia Risk)}

Im bardziej intensywna aktywność fizyczna, tym szybciej może dojść do stanu przegrzania organizmu. W badanym okresie u osób odpoczywających na powietrzu w czasie upalnych godzin okołopołudniowych ryzyko przegrzania mogło wystąpić średnio po 3 godzinach, przy czym najszybciej hipertermia groziła osobom przebywającym w 
$\min$.

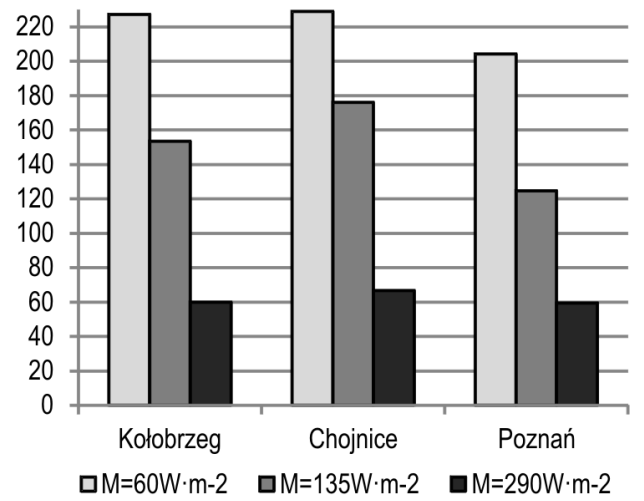

Ryc. 5. Średni czas (min.), po którym może wystąpić hipertermia w dniach upalnych o godzinie 12 UTC przy różnej aktywności fizycznej na obszarze północno-zachodniej Polski (1981-2016) Fig. 5. Average time (min.) after which hyperthermia may appear during sweltering days at 12 a.m. UTC at different physical activity in the area of north-western Poland (1981-2016)
Poznaniu. Wysiłek fizyczny, odpowiadający metabolicznej produkcji ciepła w wysokości $135 \mathrm{~W} \cdot \mathrm{m}^{-2}$, czyli np. spacer, powodował, że stan hipertermii mógł już wystąpić po 2 godzinach w Poznaniu, po 2,5 godzinach w Kołobrzegu i po blisko 3 godzinach w Chojnicach. Dodatkowa produkcja ciepła w drodze metabolizmu, związana z intensywną aktywnością fizyczną, np. szybki marsz, już po godzinie mogła przyczynić się do zbyt dużego nagromadzania ciepła w organizmie i wystąpienia udaru cieplnego (ryc. 5).

Analizy wykazały, że w dniach upalnych w południe przy braku aktywności fizycznej, warunki biotermiczne pozwalały niekiedy na przebywanie na powietrzu bez ograniczeń czasowych, ale zdarzały się też sytuacje, kiedy już po nieco godzinie mogło dojść do hipertermii. Czas pojawie-

nia się niebezpieczeństwa przegrzania w czasie podejmowania umiarkowanego wysiłku wahał się do około godziny do nawet ponad 14 godzin. Intensywne zajęcia fizyczne, gdy $\mathrm{M}=290 \mathrm{~W} \cdot \mathrm{m}^{-2}$, powodowały, że czas ten bardzo się skracał, najkrótszy odnotowany w Kołobrzegu wynosił zaledwie 33 minuty, w pozostałych stacjach nieco ponad 40 minut (tab. 7).

W czasie przebywania na powietrzu w badanych miastach Polski, w upalne południa, najczęściej po trzech godzinach dochodziło do nagromadzenia zbyt dużej ilości ciepła w organizmie. Dość często też stany takie mogły wystąpić między drugą a trzecią godziną odpoczynku, a w pojedynczych przypadkach już po godzinie. Nie zdarzały się natomiast sytuacje, kiedy do przegrzania mogło dojść już w czasie pierwszej godziny wypoczynku. Zwiększenie aktywności, odpowiadającej metabolicznej produkcji ciepła $135 \mathrm{~W} \cdot \mathrm{m}^{-2}$, powodowało, że w nieco ponad połowie przypadków ryzyko wystąpienia hipertermii mogło się pojawić już między 90 a 120 minutą. Przy większym wysiłku fizycznym np. w czasie szybkiego marszu, zagrożenie to zawsze występowało przed upływem dwóch godzin, przy czym najczęściej było ono między 30 a 60 minutą podejmowanej aktywności (tab. 8). 
Tab. 7. Maksymalny i minimalny czas (min.), po którym może wystąpić hipertermia w dniach upalnych o godzinie 12 UTC przy różnej aktywności fizycznej na obszarze północno-zachodniej Polski (1981-2016)

Table 7. Maximum and minimum time (min.) after which hyperthermia may appear during sweltering days at 12 a.m. UTC at different physical activity in the area of north-western Poland (1981-2016)

\begin{tabular}{|c|c|c|c|c|}
\hline $\begin{array}{c}\text { Metabolizm } \\
\text { Metabolism }\end{array}$ & Kołobrzeg & Chojnice & Poznań \\
\hline \multirow{3}{*}{$\mathrm{M}=60 \mathrm{~W} \cdot \mathrm{m}^{-2}$} & $\max$. & $\begin{array}{c}\text { bez ograniczeń } \\
\text { without limits }\end{array}$ & $\begin{array}{c}\text { bez ograniczeń } \\
\text { without limits }\end{array}$ & $\begin{array}{c}\text { bez ograniczeń } \\
\text { without limits }\end{array}$ \\
\cline { 2 - 5 } & $\min$. & 78,5 & 62,5 & 66,8 \\
\hline \multirow{2}{*}{$\mathrm{M}=135 \mathrm{~W} \cdot \mathrm{m}^{-2}$} & $\max$. & 847,8 & 877,8 & 857,4 \\
\cline { 2 - 5 } & $\min$. & 66,9 & 57,0 & 60,4 \\
\hline \multirow{2}{*}{$\mathrm{M}=290 \mathrm{~W} \cdot \mathrm{m}^{-2}$} & $\max$. & 112,1 & 114,5 & 109,1 \\
\cline { 2 - 5 } & $\min$. & 33,0 & 41,5 & 41,6 \\
\hline
\end{tabular}

Tab. 8. Częstość (\%) sytuacji zagrażających przegrzaniem w różnych przedziałach czasowych w dniach upalnych o godzinie 12 UTC przy różnej aktywności fizycznej na obszarze północno-zachodniej Polski (1981-2016)

Table 8 . Frequency $(\%)$ of overheating situations in various time intervals during sweltering days at 12 a.m. UTC at different physical activity in the area of north-western Poland (1981-2016)

\begin{tabular}{|c|c|c|c|c|c|c|c|c|c|}
\hline Stacja / Station & \multicolumn{3}{|c|}{ Kołobrzeg } & \multicolumn{3}{c|}{ Chojnice } & \multicolumn{3}{c|}{ Poznań } \\
\hline $\mathrm{M}\left(\mathrm{W} \cdot \mathrm{m}^{-2}\right)$ & 60 & 135 & 290 & 60 & 135 & 290 & 60 & 135 & 290 \\
\hline $0-30$ min. & 0,0 & 0,0 & 0,0 & 0,0 & 0,0 & 0,0 & 0,0 & 0,0 & 0,0 \\
\hline $30-60$ min. & 0,0 & 0,0 & 66,7 & 0,0 & 0,7 & 54,5 & 0,0 & 0,0 & 64,5 \\
\hline $60-90$ min. & 1,3 & 9,0 & 25,6 & 0,7 & 14,5 & 24,1 & 2,1 & 17,8 & 31,6 \\
\hline $90-120$ min. & 1,3 & 48,7 & 7,7 & 9,0 & 44,8 & 21,4 & 11,4 & 55,1 & 3,9 \\
\hline $120-150$ min. & 12,8 & 21,8 & 0,0 & 15,9 & 13,8 & 0,0 & 19,3 & 14,2 & 0,0 \\
\hline $150-180$ min. & 17,9 & 11,5 & 0,0 & 15,2 & 2,8 & 0,0 & 23,8 & 6,9 & 0,0 \\
\hline$>180$ min. & 57,7 & 9,0 & 0,0 & 38,6 & 23,4 & 0,0 & 39,5 & 6,0 & 0,0 \\
\hline $\begin{array}{c}\text { bez ograniczeń } \\
\text { without limits }\end{array}$ & 9,0 & 0,0 & 0,0 & 20,7 & 0,0 & 0,0 & 3,9 & 0,0 & 0,0 \\
\hline
\end{tabular}




\section{Straty wody $z$ organizmu (Water loss)}

Im bardziej intensywna aktywność fizyczna człowieka, tym większe istnieje ryzyko odwodnienia jego organizmu. Samo przebywanie w upalne południa w badanym terenie wiązało się ze średnimi stratami wody powyżej 300 g.godz. ${ }^{-1}$. Zdarzały się jednak dni, kiedy mogły być one ponad dwukrotnie wyższe, przekraczając poziom, przy którym odwodnienie u osób niezaaklimatyzowanych jest pewne. W dniach, kiedy ryzyko odwodnienia było najniższe, straty wody nie wzrastały powyżej 180 g.godz. ${ }^{-1}$. Przy aktywności fizycznej odpowiadającej metabolizmowi w wysokości $135 \mathrm{~W} \cdot \mathrm{m}^{-2}$ osiągały one średnio ponad $400 \mathrm{~g} \cdot g o d z .^{-1}$, ale wartości maksymalne wskazują na występowanie dni, kiedy spacer nad morzem wiązał się z utratą w ciągu godziny blisko $865 \mathrm{~g}$ wody, a taki sam spacer w Chojnicach mógł w tym czasie spowodować straty nawet 1017 g płynów. Zwiększenie wysiłku fizycznego, przyczyniając się do większego odprowadzenia nadmiaru ciepła w drodze parowania potu, powodowało, że w badanych miastach średnio w ciągu godziny wypoceniu ulegało ponad $600 \mathrm{~g}$ wody. Otrzymane wartości wskazują, że w godzinach okołopołudniowych zarówno w Chojnicach, jak i w Poznaniu, w ciągu jednej godziny, można było się spodziewać ewidentnego odwodnienia u osób, które nie były przystosowane do takich warunków, a mimo to zdecydowały się lub musiały podjąć zwiększony wysiłek fizyczny. We wszystkich trzech miastach zdarzały się także takie dni, kiedy nawet u osób zaaklimatyzowanych istniało ryzyko odwodnienia, a straty wody przekraczały 1100 g.godz. ${ }^{-1}$ (tab. 9).

Tab. 9. Średnie, maksymalne oraz minimalne straty wody (g.godz.-1) w dniach upalnych o godzinie 12 UTC przy różnej aktywności fizycznej na obszarze północno-zachodniej Polski (1981-2016)

Table 9. Average, maximum and minimum water loss $\left(\mathrm{g} \cdot \mathrm{h}^{-1}\right)$ during sweltering days at 12 a.m. UTC at different physical activity in the area of north-western Poland (1981-2016)

\begin{tabular}{|c|c|c|c|c|c|c|c|c|c|}
\hline Stacja / Station & \multicolumn{3}{|c|}{ Kołobrzeg } & \multicolumn{3}{c|}{ Chojnice } & \multicolumn{3}{c|}{ Poznań } \\
\hline $\mathrm{M}\left(\mathrm{W} \cdot \mathrm{m}^{-2}\right)$ & 60 & 135 & 290 & 60 & 135 & 290 & 60 & 135 & 290 \\
\hline śr. SW $\left(\mathrm{g} \cdot \mathrm{godz}^{-1}\right)$ & 317,7 & 411,7 & 607,7 & 366,5 & 462,2 & 662,2 & 377,4 & 473,8 & 675,4 \\
\hline SWmax $\left(\mathrm{g} \cdot \mathrm{godz}^{-1}\right)$ & 744,6 & 864,4 & 1121,8 & 894,5 & 1017,1 & 1279,3 & 788,5 & 908,1 & 1164,3 \\
\hline SWmin $\left(\mathrm{g} \cdot \mathrm{godz}^{-1}\right)$ & 133,9 & 220,3 & 399,5 & 177,2 & 265,3 & 448,2 & 126,9 & 213,1 & 391,5 \\
\hline$\Delta$ SW $\left(\mathrm{g} \cdot \mathrm{godz}^{-1}\right)$ & 610,7 & 644,1 & 722,3 & 717,4 & 751,8 & 831,1 & 661,6 & 695,1 & 772,8 \\
\hline
\end{tabular}


Obliczone amplitudy strat wody z organizmu, informują, że większe zróżnicowanie w gospodarce wodnej człowieka występowało w przypadku podejmowania intensywnego wysiłku fizycznego (tab. 9).

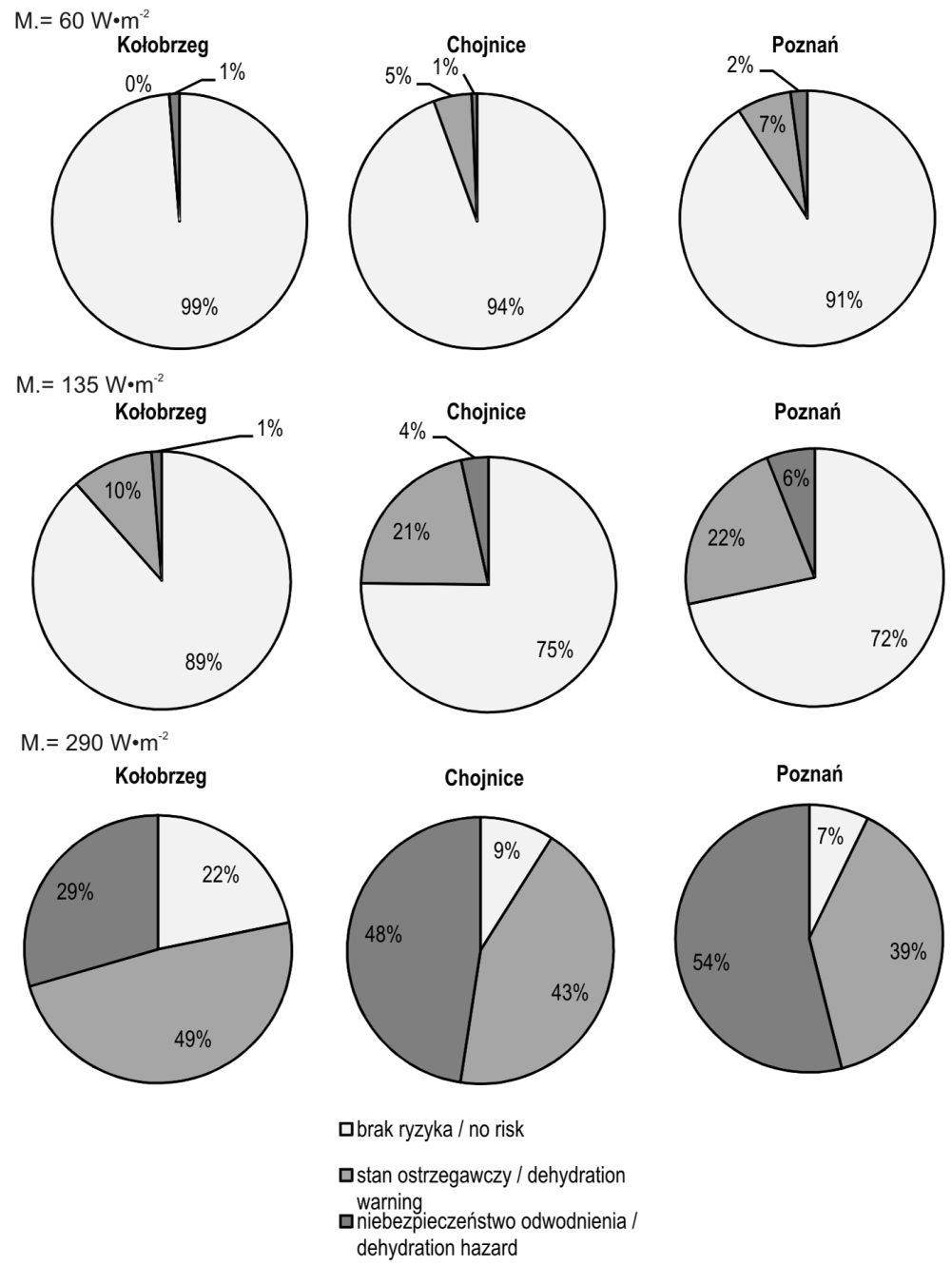

Ryc. 6. Częstość (\%) ryzyka odwodnienia w dniach upalnych o godzinie 12 UTC przy różnej aktywności fizycznej na obszarze północno-zachodniej Polski (1981-2016)

Fig. 6. Frequency (\%) of dehydration risk during sweltering days at 12 a.m. UTC at different physical activity in the area of north-western Poland (1981-2016) 


\section{Ryzyko odwodnienia (Dehydration Risk)}

Otrzymane wyniki wskazują, że w upalnych godzinach okołopołudniowych samo przebywanie w terenie otwartym, bez podejmowania wysiłku fizycznego w ponad 90\% przypadków nie wiązało się z żadnym ryzykiem wystąpienia nadmiernych strat wody z organizmu. Aktywność fizyczna, np. spacer lub wolny marsz, powodowała zwiększenie częstości stanu ostrzegawczego do 10-22\% przypadków i niebezpieczeństwo wystąpienia odwodnienia na poziomie 1-6\%, najbardziej w Poznaniu. Dość intensywna jak na panujące warunki pogodowe, aktywność fizyczna, podejmowana w Chojnicach lub Poznaniu, prowadząca do wzrostu metabolicznego ciepła do $290 \mathrm{~W} \cdot \mathrm{m}^{-2}$, była przyczyną w blisko połowie analizowanych dni sytuacji, stwarzających zagrożenie dla zdrowia zbyt dużą ilością straconej wody. W Kołobrzegu warunki takie występowały rzadziej, jedynie w jednym na trzy analizowane dni (ryc. 6).

\section{Podsumowanie i dyskusja wyników}

Kiedy temperatura maksymalna w ciągu doby przekracza $30^{\circ} \mathrm{C}$ warunki biotermiczne są dość mocno uciążliwe dla człowieka, a godziny okołopołudniowe w takich upalnych dniach szczególnie niesprzyjające dla osób, które w tym czasie podejmują się uprawiania sportu lub wykonywania pracy fizycznej w terenie otwartym.

Badania przeprowadzone w trzech miastach, zlokalizowanych na obszarze północno-zachodniej części Polski wskazały, że w czasie dni upalnych dominującym rodzajem obciążenia organizmu, u osób odpoczywających lub podejmujących umiarkowaną aktywność fizyczną, był „łagodny lub umiarkowany stres ciepła”, a subiektywnym odczuciem cieplnym ,gorąco”. Przy zwiększeniu aktywności ruchowej do poziomu intensywnego, stopień obciążenia termiczno-wilgotnościowego wzrastał natomiast do „silnego stresu ciepła”, podczas gdy subiektywne odczucie termiczne pozostawało na poziomie ,gorąco”. Takie obciążenia organizmu i odczucia cieplne występowały przeciętnie, lecz pojawiały się warunki pogodowe, przy których wysoka aktywność fizyczna prowadzić mogła również do pojawienia się „stresu ciepła”, tolerowanego jedynie przez osoby młode i zaaklimatyzowane, jak również do niebezpieczeństwa wystąpienia przegrzania organizmu niezależnie od stopnia aklimatyzacji i stanu zdrowia.

Badając odczucia parności stwierdzono, że jedynie w przypadku wzmożonej aktywności fizycznej $\left(\mathrm{M}=290 \mathrm{~W} \cdot \mathrm{m}^{-2}\right)$ mogło dojść do zwiększenia częstości intensywnej bądź umiarkowanej parności. Niebezpieczny w dniach upalnych był natomiast wzrost częstotliwości tętna, który przy podejmowaniu wysiłku fizycznego już w stopniu umiarkowanym wzrastał do poziomu ostrzegawczego. Analizy wykazały także, że u osób pozostających w spoczynku średnio po ok. 3,5 godzinach mogło pojawić się 
ryzyko hipertermii. Zwiększenie aktywności fizycznej do umiarkowanej skracało ten czas do 2-3 godzin, a do intensywnej już tylko do godziny.

Poważnym zagrożeniem w dniach upalnych było ryzyko odwodnienia organizmu. Podczas podejmowania intensywnego wysiłku fizycznego w Chojnicach i Poznaniu występowało ono w prawie połowie przypadków, nad morzem w jednym na trzy badane dni. Zmniejszenie aktywności ograniczało to zagrożenie. Przy poziomie umiarkowanym spadało ono do ok. 10-22\%, podczas samego odpoczynku nie przekraczało $6 \%$.

Ilość straconej wody w czasie odpoczynku wynosiła średnio nieco powyżej 300 g.godz. ${ }^{-1}$, choć zdarzały się dni kiedy była ona dwukrotnie wyższa. Wzrost aktywności fizycznej do umiarkowanej wiązał się ze stratami wody średnio o ok. $100 \mathrm{~g} \cdot$ godz. $^{-1}$ większymi, a dalsze zwiększanie wysiłku mogło prowadzić do odwodnienia, przy przeciętnych stratach wody przekraczających 600 g.godz. ${ }^{-1}$, choć odnotowano również takie warunki pogodowe, przy których w czasie intensywnych zajęć ruchowych straty wody wzrastały nawet powyżej $1100 \mathrm{~g} \cdot \mathrm{godz} .^{-1}$.

Porównując badane miejscowości, można stwierdzić, że Kołobrzeg charakteryzował się dość mocno obciążającymi warunkami odczuwalnymi w upalne godziny okołopołudniowe. Przede wszystkim zaznaczyło się tam silne niebezpieczeństwo przegrzania organizmu i jedynie tam stwierdzono możliwość wystąpienia subiektywnego odczucia „upalnie”. Niekorzystne warunki biotermiczne, odnotowane w tej atrakcyjnej pod względem turystycznym miejscowości, wynikać mogą z lokalizacji stacji w obrębie gęstej zabudowy uzdrowiskowej, co wpływać może w znaczącym stopniu na podwyższenie wartości temperatury powietrza, w porównaniu z wartościami, których oczekiwać można w samej strefie plaży (Kozłowska-Szczęsna i in. 2002). Stosunkowo wysoką częstość obciążeń cieplnych, określonych za pomocą wskaźnika HSI u osób z umiarkowanym wysiłkiem fizycznym $\left(135 \mathrm{~W} \cdot \mathrm{m}^{-2}\right)$, stwierdzili w swych badaniach Błażejczyk i Kunert (2011), Kozłowska-Szczęsna i in. (2002) oraz Krawczyk (2001). Bąkowska (2009), analizując zmiany przebiegu dobowego wybranych wskaźników latem w Kołobrzegu dla lat 1981-1990, stwierdziła, że średnia wartość wskaźnika STI w południe w okresie od czerwca do sierpnia przekracza nieco $30^{\circ} \mathrm{C}$, co może je określać jako warunki komfortowe, natomiast metaboliczna produkcja ciepła w tym czasie nie powinna wzrastać powyżej $193,1 \mathrm{~W} \cdot \mathrm{m}^{-2}$, co wyklucza możliwość podejmowania intensywnego wysiłku fizycznego nie tylko w samych dniach upalnych, ale i w pozostałych dniach okresu letniego. Badania Koźmińskiego i Michalskiej (2010, 2011), przeprowadzone dla lat 1986-2007 dowiodły, że dominującym odczuciem cieplnym na wybrzeżu na przełomie lipca i sierpnia jest „gorąco”, a w przypadku maksymalnych wartości wskaźnika STI - „bardzo gorąco”, przy czym średnia maksymalna temperatura odczuwalna STI w lipcu w samym Kołobrzegu wynosi $46^{\circ} \mathrm{C}$.

W Kołobrzegu odnotowano także podwyższoną wilgotność powietrza, co - jak wykazali Koźmiński i Michalska (2011) - jest niekorzystnym elementem pogody 
strefy wybrzeża. Z tego względu Kołobrzeg w dniach z wysoką temperaturą powietrza cechował się występowaniem dużej parności, choć jednocześnie istniało tam najmniejsze ryzyko odwodnienia organizmu. Podobne wyniki wysokiej parności, występującej w pasie nadmorskim otrzymali Araźny i Smukała (2011), wiążąc je z występowaniem pogody antycyklonalnej, bezwietrznej oraz niżowej z adwekcją z sektora południowego, wskazując też na zwiększanie dni parnych w Helu.

Analizy dowiodły także, że w przypadku Chojnic, położonych na Pojezierzu Krajeńskim, i Poznania, reprezentującego mniej urozmaiconą rzeźbę terenu, w czasie samego odpoczynku występowały podobne warunki bioklimatyczne, nieco mniej obciążające niż nad morzem. Sprzyjające uwarunkowania pogodowe dla turystyki w Chojnicach, które wynikają z lokalizacji stacji w otoczeniu lasów i jezior, wykazali Kalbarczyk i Kalbarczyk (2007), obliczając wartość wskaźnika klimatyczno-turystycznego, na podstawie którego określili występujące tam w sezonie wakacyjnym warunki klimatyczne jako „bardzo dobre”, a w sierpniu nawet „doskonałe”. Jak jednak pokazały badania Więcława (2013), przeprowadzone dla lat 1976-2010, w czasie upalnych dni średnia temperatura maksymalna powietrza w ciągu dnia w powietrzu zwrotnikowym wynosi $32,2^{\circ} \mathrm{C}$, dodatkowo w kolejnych latach zaznaczył się jej szybki przyrost, który w okresie 1976-2000 wyniósł ok. 0,7 C (Więcław 2013). Oznaczać to może pogarszanie się w Chojnicach warunków biotermicznych podczas okresów upalnych. W czasie aktywności umiarkowanej korzystniejsze warunki, cechujące się mniejszym ryzykiem przegrzania czy też niższą parnością, odnotowano w Chojnicach niż w Poznaniu, choć różnice między tymi miejscowościami były niewielkie; zaznaczały się one dopiero przy intensywniejszej aktywności fizycznej. Nieco bardziej uciążliwe warunki pogodowe występowały w Poznaniu, co może wynikać z lokalizacji stacji meteorologicznej w bliskim sąsiedztwie dużej aglomeracji miejskiej.

\section{Literatura}

Araźny A., Smukała K., 2011, Ocena bodźcowości warunków termiczno-wilgotnościowych w Polsce w preekroju potudnikowym w okresie 1976-2005, Annales Universitatis Mariae Curie-Skłodowska, LXVI, 2, B, Lublin - Polonia, 77-90.

Bąkowska M., 2009, Zmienność præebiegu dobowego wybranych wskaæników bioklimatycznych w Kotobrzegu w okresie letnim w latach 1981-1990, Przegląd Geograficzny, 81 (3), 373-397.

Błażejczyk K., 2004, Bioklimatyczne uwarunkowania rekreacji i turystyki w Polsce, Prace Geograficzne, 192, IGiPZ PAN, Warszawa.

Błażejczyk K., Kunert, A., 2011, Bioklimatyczne uwarunkowania rekreacji i turystyki w Polsce, Monografie, 13, IGiPZ PAN, Warszawa.

Cebulak E., Limanówka D., 2007, Dni z ekstremalnymi temperaturami powietræa w Polsce, [w:] K. Piotrowicz, R. Twardosz (red.), Wahania klimatu w rósnych skalach præestrzennych i czasowych, IGiGP UJ, Kraków, 185-194. 
Kalbarczyk E., Kalbarczyk R., 2007, Klimatyczne uwarunkowania turystyki na Pomorzu Środkowym, Przegląd Naukowy Inżynieria i Kształtowanie Środowiska, 16, 2 (36), 52-63.

Kondracki J., 2002, Geografia regionalna Polski, Wydawnictwo Naukowe PWN, Warszawa.

Kossowska-Cezak U., Skrzypczuk J., 2011, Pogoda upalna w Warszawie (1947-2010), Prace i Studia Geograficzne, 47, 139-146.

Kozłowska-Szczęsna T., Błażejczyk K., Krawczyk B., Limanówka D., 2002, Bioklimat uzdrowisk polskich i możliwość jego wykorzystania w lecznictwie, Monografie, 3, IGiPZ PAN, Warszawa.

Kozłowska-Szczęsna T., Krawczyk B., Kuchcik M., 2004, Wpływ środowiska atmosferycznego na zdrowie i samopoczucie cztowieka, Monografie, 4, IGiPZ PAN, Warszawa.

Koźmiński C., Michalska B., 2010, Zmienność liczby dni gorqcych i upalnych oraz odczucia cieplne w strefie polskiego wybræe: $a$ Battyku, Acta Agrophysica, 15 (2), 347-357.

Koźmiński C., Michalska B., 2011, Meteorologicæne uwarunkowania rowwoju turystyki i rekreacji w strefie polskiego wybrze:a Battyku, Acta Balneologica, 1, 68-74.

Krawczyk B., 2001, Ryzyko wystapienia stresu ciepta w wybranych uzdrowiskach polskich, Balneologia Polska, 43 (1-2), 88-93.

Kuchcik M., 2006, Fale upatów w Polsce w latach 1993-2002, Przegląd Geograficzny, 78 (3), 397-412.

Mizera K., Pilis W., 2008, Znaczenie żywienia w sportach sitowych w róźnych fazach ontogenezy cztowieka, Medicina Sportiva Practica, 9 (4), 73-84.

Tomczyk A. M., 2012, Pogoda upalna w Poznaniu w latach 1980-2011, Słupskie Prace Geograficzne, 9, 155-162.

Twardosz R., 2009, Fale niezwyktych upatów w Europie na poczatku XXI wieku, Przegląd Geofizyczny, 3-4, 193-204.

Więcław M., 2013, Synoptyczne wwarunkowania wystepowania dni ekstremalnych pod wagledem termic:nym w Chojnicach w okresie lat 1976-2010, Journal of Health Sciences, 3 (14), 27-39.

\title{
Strony internetowe
}

https://www.igipz.pan.pl/Bioklima-zgik.html (5.01.2017).

https://www7.ncdc.noaa.gov (25.11.2016).

\author{
Monika Okoniewska \\ Uniwersytet Kazimierza Wielkiego w Bydgoszczy \\ Wydziat Kultury Fizycznej, Zdrowia i Turystyki \\ Instytut Geografii \\ Pl. Kościeleckich, 85-033 Bydgos:c\% \\ monika.okoniewska@ukw.edu.pl
}


